\title{
Petro Topilnitskij \\ CORROSION PROTECTION OF OIL PRODUCTION AND REFINERY EQUIPMENT
}

\author{
Lviv Polytechnic National University, Lviv, Ukraine \\ 12 Bandera str., 79013 Lviv, Ukraine
}

\begin{abstract}
The review of methods of industrial equipment corrosion prevention is presented. Application of technological means using chemical reagents and surfaceactive substances is considered, namely dehydration and desalting of hydrocarbon products of deposits by surfaceactive substances - so called demulsifiers. Corrosion inhibitors and neutralizing agents for protection of condensation-refrigeration equipment and overheads of atmospheric columns are examined. The amount of reagents to be used and the process conditions were determined.
\end{abstract}

Keywords: corrosion, corrosion prevention, oil emulsion, desalting, dehydration, surface-active substances, demulsifier, neutralizer, corrosion inhibitor.

\section{Introduction}

Oil industry, that is production, transportation and processing of oil consumes about $8 \%$ of all metal which is made in the world. At the same time, oil industry is characterized by high corrosive activity of media at all the stages of production, transportation and processing of oil. In this industry the corrosive wear of metal determines duration and fail-safety of equipment, duration of overhaul periods and expenses of equipment repairs. Losses caused by corrosion consist not only of the loss of metal mass but also cause worsening of equipment functional properties. Latter considerably exceed direct losses, such as suspension of production, explosions, fires, ecological catastrophes related to the accidents on oil- and gas pipelines, damage of reservoirs, piping, breakage of vehicles, surface and underground structures, etc.

Thus, the whole complex of measures directed on prevention and elimination of corrosion damage results is formed in oil industry. Corrosion-proof materials for oil equipment and piping, chemical reagents and surface-active substances (SAS) for extraction and neutralization of corrosive-active components of hydrocarbon products are used for the purposes mentioned above.

Technological measures making use of chemical reagents and surface-active substances in oil industry are stated below.

\subsection{Dehydration and desalting of oil emulsions}

Dehydration and desalting of oil emulsions means water and chlorous salts extraction from oils and condensates. Demulsifiers are used for the extraction.

Surface-active substances in aqueous solutions are divided into three basic groups: anionic, cationic and nonionogenic.

Anionic substances in aqueous solutions dissociate into negatively charged ions containing hydrocarbon part of a molecule and positively charged ions of metal or hydrogen.

Carbonic acids and salts, sulphoethers (alkylsulphates), alkylsulphonates and alkylarylsulphonates are anionic-active substances.

Cationic-active substances in aqueous solutions dissociate into positively charged radical and negatively charged ion of acid. Nitrous bases belong to cationicactive substances mainly.

Non-ionogenic substances in aqueous solutions do not dissociate into ions. They are produced by addition of ethylene oxide to the organic substances with the mobile hydrogen atom, in other words, to those containing carboxyl, hydroxyl, sulphohydril, amine or amide groups. Organic acids, diatomic alcohols (glycols), phenols, mercaptanes, amines and amides acids may be raw materials for the synthesis of non-ionogenic SAS.

Non-ionogenic surface-active substances are more effective, the technological process of their obtaining is simpler in comparison with SAS of other groups. Moreover, it is possible to get different surface-active substances with various properties from the same raw material at the same plant.

Such demulsifiers, as block-copolymers of ethylene and propylene oxides, obtained on the basis of propylene or ethylene glycols, ethyleneamide and monoethanolamine, have the greatest demulsifying activity among non-ionogenic SAS. High efficiencies of above-mentioned compounds are caused by polyoxypropylene glycol used as hydrophobic part. Molecular mass of polyoxypropylene glycol could be changed in wide ranges. Changing ratio between block molecular masses of polyoxypropylene glycol and polyoxyethylene glycol in macromolecules of block-polymers it is possible to get a wide range of compounds with different properties. 
The increase of branching of block-copolymer macromolecule increases an area which is occupied by a molecule at adsorption on phase boundary. At the same time demulsifier consumption decreases. In order to increase the branching of "pluronic" molecule, one may introduce minor amount of hydrophilic agent (ethylene oxides) to the hydrophobic block or vice versa hydrophobic agent (propylene oxide) may be introduced to the hydrophilic block. Introduction of additional amount of ethylene oxide to the polypropelene glycol block obviously will multiply hydrophilic property of demulsifier resulting in the decline of its diffusing ability in the oil environment. That is why we decided to introduce the additional amount of propylene oxide into polyoxyethylene block by alkylation of polyoxypropylene block with mixture of ethylene and propylene oxides.

\subsection{Neutralization of acid components}

Acid components may be presented in crude oil. With the purpose of decreasing $\mathrm{HCl}$ formation and reduction of muriatic corrosion intensity it is recommended to neutralize the desalted oil with sodium carbonate, sodium hydroxide and their mixture in order to transform calcium and magnesium chlorides into sparingly soluble hydconsumptions or carbons and sodium chloride, which does not hydrolyze under the conditions of primary plants.

Danger of alkaline cracking of equipment and gumming-up of the chimneys rises when only sodium hydroxide is used. In order to avoid alkaline fragility, it is recommended to add dilute solution of caustic soda (3-8 g per $1 \mathrm{~m}^{3}$ of oil) with obligatory stirring in the special mixer device.

\subsection{Neutralization of overheads of atmospheric columns}

It is the chemical interaction between chlorous hydrogen and sulphuretted hydrogen.

Inorganic and organic compounds with high basic properties, such as ammonia, morpholine or organic amines are used as neutralizing agents for defence of condensation-refrigeration equipment. Ammonia was most widespread through its relative cheapness and high neutralizing ability. However the main lack of its application was difficulty of confinement of $\mathrm{pH}$ optimum value in the assigned interval.

\subsection{Use of corrosion inhibitors}

As a rule, surface-active substances which produce a protective film over metal surface are inhibitors.

Inhibition is one of the simplest and economical methods of corrosion protection. However inhibitors must meet the following requirements: maximal protective action and minimal consumption; absence of influence on the technological process proceeding, quality of products and work of catalysts. They must be economic, stable and harmless for attending personnel and the environment.

Different organic compounds containing nitrogen, sulphur, oxygen, phosphorus, silicon or other substances are used as inhibitors. Petroleum refining mainly uses nitrogenated-containing compounds as inhibitors.

Inhibitors soluble in a hydrocarbon phase have undoubted advantages. They are able to form hydrophobic film over surface of metal. The first step of inhibitor action is water displacement. The ability to displace water and aggressive liquids from the surface of metal mainly determines protective efficiency of inhibitor.

The chemisorption layer of inhibitor formed over the metal surface is the main component of protective action. Chemisorption is determined by forces of chemical interaction which predetermines considerable energy of connection between inhibitor molecules and metal surface.

At adsorption on the surface of iron or other metal containing uncompleted $d$-sublevels, organic inhibitors serve as donors and metallic ions - as acceptors of electrons. Strength of adsorption connection depends on electronic density over the adsorption-active area of inhibitor molecule. That is why the protective effect of inhibitors must be related to the parameters which characterize electronic-donor properties of molecules. Atoms with an unshared electronic pair or areas containing p-bound electrons are main adsorptions areas in the inhibitors molecules.

There are three types of inhibitors: chemisorption compounds of donor type (sulphonates, amides); chemisorption compounds of acceptor type (amines, amides, organic acids, surface-active compounds containing phosphorus or sulphur in their molecules); fastacting SAS of screening type (oxidated petroleum products, such as paraffines, petrolatum, as well as fatty acids, glycerides, fats).

As inhibitors are used compounds containing the following molecular fragments:<smiles>[R]C1=NCCN1</smiles>
$\mathrm{RNH}_{2}$<smiles>[R][R]C([CH][Co]([R])O[R])COC([R])[R]</smiles>

Alkylamines Imidazolines Glycerides (fats)

Molecules which have a free electronic pair, as well as p-electrons are presented in these fragments. Thus, these inhibitors belong to the latter two types listed above and can operate using all possible mechanisms of corrosion inhibition. Development of such inhibitors will allow, obviously, to obtaine products with a wide spectrum of application. 
Presently, most of inhibitors which are used in petroleum refining are derivatives of imidazoline [1].

There are the same problems of choice of the optimum composition when using imidazolines, as well as using other inhibitors. The system may be treated in any place. It means that inhibitor may dissolve or easily disperse in water or in oil.

Plenty of corrosion inhibitors are presently known for metals defence. The large assortment of these matters is explained by the variety of media and conditions under which inhibitors are used. Moreover, many chemical compounds have inhibiting properties.

Inhibitors of TAL-M type were widely used in industry for the corrosion protection of apparatus and equipment [2]. Corrosion takes place under the action of oil, gas condensate, brines and products of water condensates (which contain the dissolved aggressive gases, such as chlorous hydrogen, carbon dioxide, hydrogen sulphide, etc.).

The package of "Hercules" reagents is developed by the laboratory of technology of oils preparation of JSC "VNIINP" (Russia). "Hercules-30617" was tested for a corrosion protection of condensation refrigeration equipment (CRE) of the primary oil processing plants [3]. The results obtained testify that "Hercules" reagents provide the effective corrosion protection of equipment.

Industrial application of Kemelix 1123X corrosion inhibitor, produced by ISI firm (Great Britain) showed satisfactory results. It is recommended to add 3-5 g/ton of this film-forming inhibitor.

„RENA-Naftokhim-8" inhibitor is intended for the corrosion protection of oil-and-gas equipment and waterpipes which support layer pressure. Corrosion is caused by the hydrogen sulphide, carbonic acid, and mineralized stratal waters.

"DEOL-4241" inhibitor is intended for the corrosion protection of apparatus and equipment in the media of oil, aqueous solutions of salts, condensates, hydrocarbons and water vapours, aggressive gases [4]. It is an inhibitor with optimal composition consisting of amides and polyamine naphthenic acids. Hydrophobic layer is formed due to the amide adsorption over the metal surface. Such a layer prevents interaction between aggressive medium and metal. Interaction between amine and sulphuretted hydrogen (or hydrochloric acid) neutralizes the main part of acid gases.

\section{Experimental}

Non-ionogenic demulsifier used for the investigation of dehydration and desalting processes of oil emulsion was synthesized by us on the basis of ethylene and propylene oxides [5].

Macromolecule of block-copolymer of synthesized demulsifier has the following formula:

where $\mathrm{R}$ is $\mathrm{H}$ - or $\mathrm{CH}_{3}$ - radical

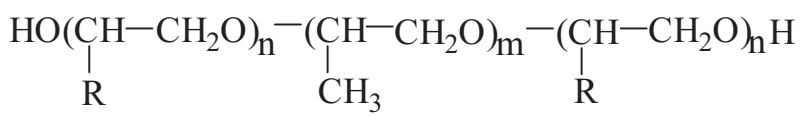

On the basis of laboratory concentrate marketable forms of demulsifiers were developed. Demulsifier efficiency was studied in temperature-controlled separating funnel. The effect of demulsifier consumption, temperature, oil nature and concentration of demulsifier active form was examined.

Emulsions of Dolyna, Gnidynci and West-Siberia oils differed by content of dispersive phase were taken for investigations (Table 1). Apparently, at the identical demulsifier consumption (calculated relatively to 1 ton of emulsion) its amount per interphase unit is different. In order to investigate the efficiency of dehydration process upon demulsifier consumption it is necessary to recalculate their consumptions ( $\mathrm{g} / \mathrm{ton})$ for the specific amounts of demulsifier on the interphase of emulsion $-\mathrm{g} / \mathrm{cm}^{2}$.

Various domestic and foreign nitrogenated products, such as beta-oxyethylenediamine, diethylenetriamine, triethanolamine, morpholine, cyclohexylamine and ammonia were investigated as neutralizing agents.

\section{Characteristics of emulsion stabilizers}

Table 1

\begin{tabular}{|l|c|c|c|}
\hline \multicolumn{1}{|c|}{ Characteristics } & \multicolumn{2}{c|}{ Oli emulsions of: } \\
\cline { 2 - 4 } & Dolyna & Gnidynci & West-Siberia \\
\hline Dispersive phase content, mass \% & 19.30 & 24.85 & 47.00 \\
\hline Specific area of phase surface, $\mathrm{cm}^{2} / \mathrm{cm}^{3}$ & 6447 & 5875 & 0.0927 \\
\hline Stabilizer content, mass \% & 0.2238 & 0.0641 & 125.9 \\
\hline Stabilizer adsorption, $\left(\mathrm{g} / \mathrm{cm}^{2}\right) \cdot 10^{8}$ & 199.2 & 62.6 & 17.51 \\
\hline Stabilizer composition, mass \% & & 40.75 & 19.14 \\
paraffines (P) & 71.81 & 8.41 & 63.35 \\
resins (R) & 13.74 & 50.84 & 0 \\
asphaltenes (A) & 14.45 & 0 & 5.0 \\
mechanical impurities & 0 & 1.4 & asphaltene type \\
\hline (R+A)/P & 0.4 & mixed type & \\
\hline Stabilizer type & paraffin type & & \\
\hline
\end{tabular}


Qualitative characteristics of commodity neutralizers met normative documents.

Neutralizing ability of a neutralizer was determined by $\mathrm{HCl}$ amount, which was neutralized at titration of reagent (gram of $\mathrm{HCl}$ per gram of neutralizer) till $\mathrm{pH}$ value became 6.0:

$$
E_{n}=1.83 \cdot \frac{V_{a c i d}}{V_{n}}
$$

where 1.83 is a conversion coefficient;

$V_{\text {acid }}$-volume of solution of $1 \mathrm{~N}$ hydrochloric acid, necessary for titration of neutralizer till $\mathrm{pH}=6.0, \mathrm{~cm}^{3}$

$V_{n}$ - volume of neutralizer solution, necessary for determination of its efficiency, $\mathrm{cm}^{3}$

Inhibiting effects of Dodicor 3747, Kemelix 1123X, TAL-25-13-R, RENA-Naftokhim, OR-2K, AKS, DEOL4241 inhibitors were compared.

The active bases of different inhibitors are listed below:

- amides of polyamine naphthenic acids - for Dodicor 3747;

- organic nitrogenated compound in organic solvent - for Kemelix 1123X;

- fatty basis of tall oil - for TAL 25-13-R;

- amidoamines with amidozolines and amine salts for RENA-Naftokhim;

- monoethanolamine vat residue with benzyl quinoline compounds - for OR-2K;

- nitrogenated organic phosphates - for AKS;

- amides of polyamine naphthenic acids - for DEOL-4241.
The qualitative characteristics of commodity neutralizers met normative documents.

Inhibitor efficiencies were estimated by gravimetric method [6]. Metal plates made from St20 steel with total area more than $30 \mathrm{~cm}^{3}$ were control samples. Exposition time was 3 hours, experimental temperature was $343 \mathrm{~K}$.

The following model systems were used for experiments:

- monophase system was a medium according to GOST 9.506-87. It simulates medium of stratal waters and contains chlorides of magnesium, potassium and sodium;

- edophasic system simulates petroleum -water system and contains mineralized water ( $1 \%$ solution of $\mathrm{NH}_{4} \mathrm{Cl}$ and $1 \%$ solution of $\mathrm{NaCl}$ ).

Experiments were carried out in monophase and diphasic media. TS-1 jet engine fuel was used as hydrocarbon phase. Petroleum-water phase ratio was 1:10.

\section{Results and Discussion}

\subsection{Dehydration and desalting of oil emulsions}

We examined the effect of emulsion natural stabilizers on emulsion breakdown.

Dependence of residual water content in oil emulsions with different natural stabilizers upon the concentration of synthesized demulsifier is represented in Fig. 1 (a,b,c and d).
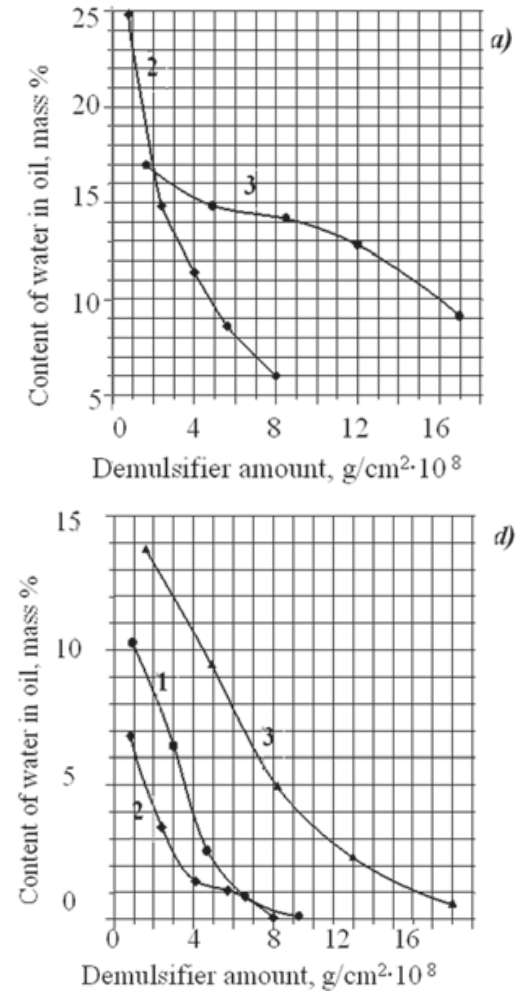
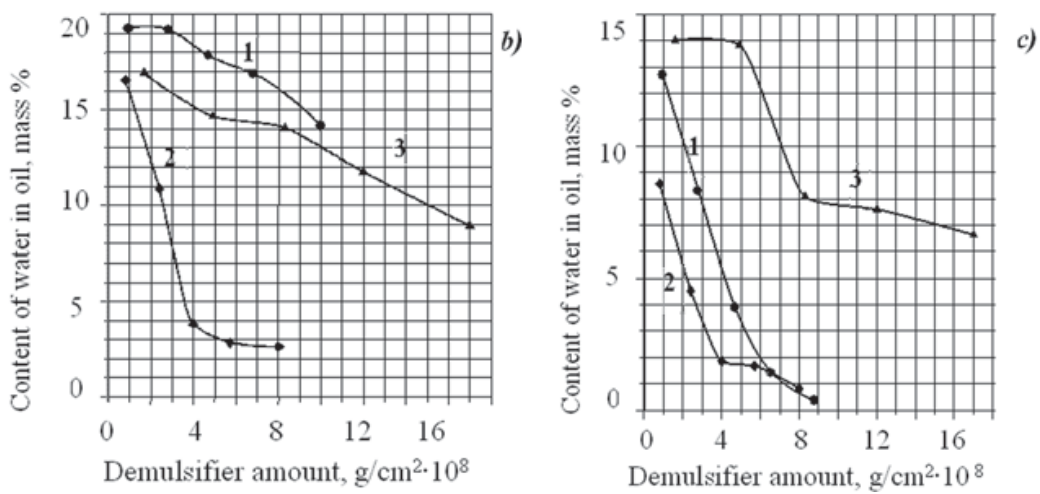

Fig. 1. Dependence of residual water content in oil emulsions upon demulsifier amount over unit of interface at: $293 \mathrm{~K}$ (a), $313 \mathrm{~K}$ (b), $333 \mathrm{~K}$ (c), $353 \mathrm{~K}$ (d)

1 - Dolyna oil; 2 - Gnidynci oil; 3 - West-Siberia oil 
As we can see from the figures above, the necessary amount of demulsifier per unit of interphase depends upon type of emulsion stabilizer for achieving identical quality of oil preparation. At low temperatures (under $313 \mathrm{~K}$ ) the greatest amount of demulsifiers is needed for emulsions of Dolyna and West-Siberia oils. It can be explained by the presence of the greatest amount of natural stabilizers on phase boundary in these emulsions. However, already at $333 \mathrm{~K}$ the amount of demulsifier necessary for emulsion breakdown is 3-4 times less for Dolyna oil in comparison with WestSiberia oil.
Laboratory and commercial tests of different commodity forms of synthesized demulsifier (PM, PM1441) show their high efficiencies within wide ranges of temperature and consumption [7,8].

Long-lasting commercial tests of Hercules-1017 oilsoluble demulsifier (produced by "Coltec International", Russia), PM-1441 oil-water-soluble demulsifier and PM water-soluble demulsifier (JSC "Factory of fine organic synthesis "Barva") were carried out at GK-3/1 electrical desalting plant of JSC "Ukrtatnaphta".

On the basis of commercial tests dependences of quality indexes of oil preparation upon demulsifier consumption were graphed (Fig. 2).
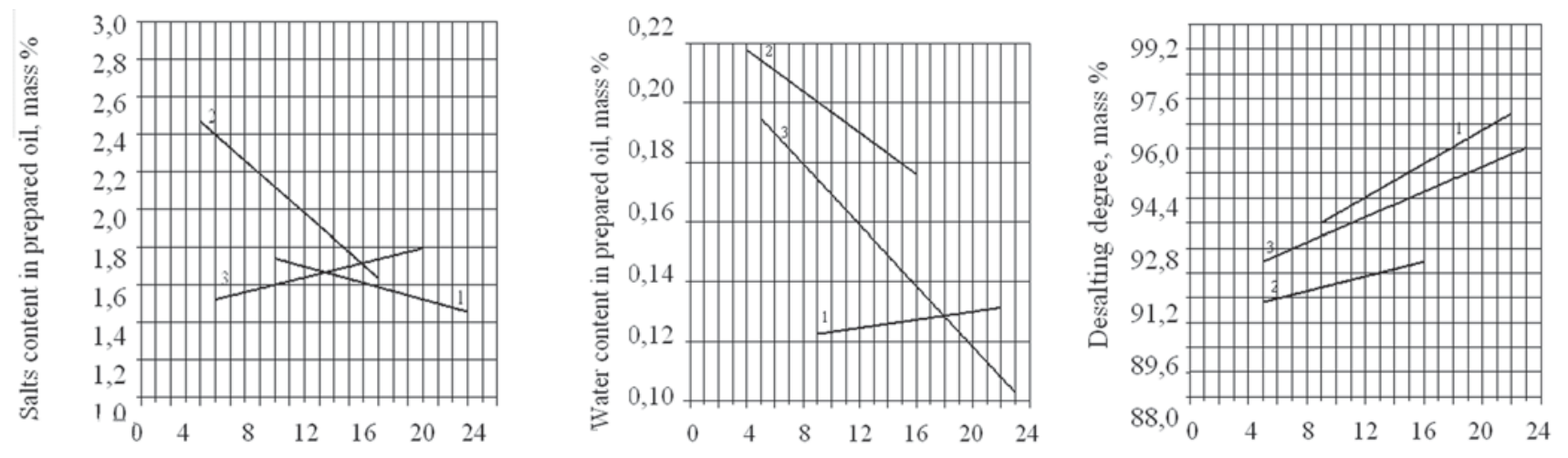

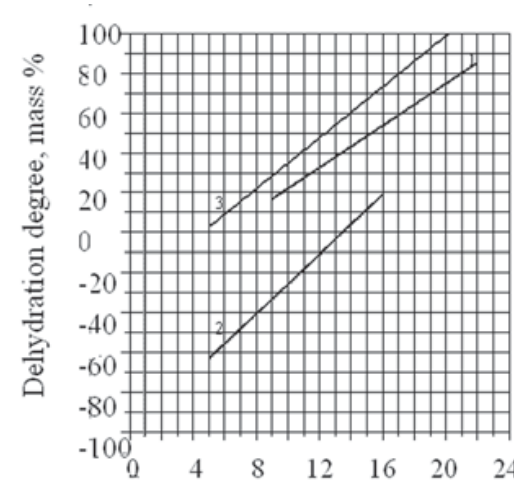

The dependence of residual content of salts and water in oil upon demulsifier consumption is represented in Figs. 2a and b. We used test data of PM, Hercules1017 and PM-1441 demulsifiers, as well as results of later use of PM and PM-1441 demulsifiers at $1^{\text {st }}$ plant (for increase in data amount).

One can see that at desalting (Fig. 2a) PM-1441 demulsifier is effective at low consumptions (5-13 g/ton) and Hercules demulsifier is effective at consumptions higher than $13 \mathrm{~g} /$ ton. The increase of PM-1441 consumption increases salts content in the prepared oil. This fact may be explained by the addition of subquality products with high content of salts and water to raw material. The degree of desalting increases with increase of PM-1441 consumption, as well as consumptions of other demulsifiers. PM demulsifier has a stable influence
Fig. 2. Dependence of prepared oil quality upon demulsifier consumption:

1 - PM; 2 -Hercules-1017; 3 -PM-1441 on quality of oil preparation in the wide range of consumptions (9-22 g/ton).

At dehydration (Fig. 2b) PM-1441 and Hercules1017 demulsifiers improve quality of oil preparation with their consumptions increase. Moreover, at high consumptions PM-1441 demulsifier is better for water extraction than Hercules-1017. Change of PM consumption in all the explored ranges of consumption insignificantly affects the residual content of water in oil, as well as in the case of desalting process.

Of course, residual content of water and salts in oil depends not only on the demulsifier consumption but also upon their initial content, therefore dependences of degrees of desalting and dehydration upon the demulsifier consumptions were graphed (Figs. 2c and d). The increase of demulsifier consumptions increases their efficiency. 
In any case, PM and PM-1441 demulsifiers are the best both at oil desalting and dehydration. Results of their application at JSC "Ukrtatnafta" during the last years are represented in Table 2.

Averaged results of demulsifier application at JSC "Ukrtatnafta"

\begin{tabular}{|c|c|c|c|c|c|}
\hline \multirow{2}{*}{ Year } & \multicolumn{2}{|c|}{ Content in crude oil: } & \multicolumn{2}{c|}{ Content in prepared oil: } & $\begin{array}{c}\text { PM } \\
\text { consumption, } \\
\text { g/ton }\end{array}$ \\
\cline { 2 - 5 } & salts, $\mathrm{mg} / \mathrm{l}$ & water, mass $\%$ & salts, mg/l & water, mass \% & $8.9-22.1$ \\
\hline \multicolumn{7}{|c|}{ PM } \\
\hline 1998 & $18.4-57.1$ & 0.31 & 1.59 & 0.21 & $10.0-20.4$ \\
\hline 1999 & $21.2-83.3$ & 0.28 & 1.19 & 0.12 & $19.0-20.3$ \\
\hline 2000 & $25.5-123.4$ & 0.21 & 1.32 & 0.11 & $14.0-19.0$ \\
\hline 2001 & $43.9-72.4$ & 0.12 & 2.16 & 0.10 & $14.0-20.5$ \\
\hline 2002 & $35.8-83.6$ & 0.15 & 2.74 & 0.11 & $10.0-15.0$ \\
\hline 2003 & $17.5-60.1$ & 0.14 & $0.85-1.86$ & 0.09 & $5.0-10.0$ \\
\hline \multicolumn{7}{|c|}{ PM-1441 } \\
\hline 2004 & $7.4-76.5$ & 0.13 & $0.92-2.5$ & 0.09 & $6.0-10.0$ \\
\hline 2005 & $6.5-68.0$ & 0.18 & $0.55-1.8$ & 0.10 & $5.5-11.0$ \\
\hline 2006 & $6.8-98.5$ & 0.25 & $0.49-1.7$ &
\end{tabular}

It is also necessary to take into consideration the cost of oil preparation, including the cost of demulsifier. For the calculation of cost of oil preparation (cost per 1 ton) those demulsifier consumptions were indicated, within the limits of which efficiency of demulsifier was the greatest. Taking into account that the cost of demulsifiers can change, the cost of PM demulsifier was accepted as 1 . Scale factors were accepted for the other demulsifiers (Table 3).

\section{Cost comparison of oil preparation with different demulsifiers}

Table 3

\begin{tabular}{|l|c|c|c|c|c|}
\hline \multirow{2}{*}{ Demulsifier } & \multirow{2}{*}{$\begin{array}{c}\text { Ratio between demulsifier cost } \\
\text { and PM cost }\end{array}$} & \multicolumn{2}{|c|}{ Demulsifier consumption, g/ton } & \multicolumn{2}{c|}{$\begin{array}{c}\text { Relative cost of oil } \\
\text { preparation (for 1 ton) }\end{array}$} \\
\cline { 3 - 6 } & 1 & minimum & maximum & average & average \\
\hline PM & 1.62 & 8 & 22 & 15 & 1.00 \\
\hline Hercules-1017 & 1.44 & 13 & 16 & 14.5 & 1.57 \\
\hline PM-1441 & 5 & 13 & 9 & 0.86 \\
\hline
\end{tabular}

Though the cost of PM-1441 demulsifier is higher than PM demulsifier, the cost of oil preparation using PM-1441 is less than using PM. Hercules-1017 has the worse efficiency, as well as the highest cost.
Averaged results of oil preparation at refineries of Russia, which have similar structure, flow charts and equipment as Ukrainian refineries have, are represented in Table 4 [9].

Table 4

Comparison of oil preparation at Russian refineries and JSC "Ukrtatnafta"

\begin{tabular}{|c|c|c|c|c|c|}
\hline \multirow{2}{*}{ Refinery } & \multicolumn{2}{|c|}{ Content in crude oil: } & \multicolumn{2}{|c|}{ Content in prepared oil: } & \multirow{2}{*}{$\begin{array}{c}\text { Desalting } \\
\text { degree, } \\
\text { mass } \%\end{array}$} \\
\hline & $\begin{array}{c}\text { chlorides, } \\
\mathrm{mg} / \mathrm{l}\end{array}$ & $\begin{array}{l}\text { water, } \\
\text { mass } \%\end{array}$ & $\begin{array}{l}\text { chlorides, } \\
\mathrm{mg} / \mathrm{l}\end{array}$ & $\begin{array}{l}\text { water, } \\
\text { mass } \%\end{array}$ & \\
\hline 1 & 2 & 3 & 4 & 5 & 6 \\
\hline JSC "Saratovskiy NPZ" & 55.9 & 0.41 & 2.5 & 0.04 & 95.53 \\
\hline JSC "Kirishnefteorgsintez" & $40-120$ & $0.1-0.6$ & $2.0-4.0$ & 0.03-0.09 & 96.25 \\
\hline JSC "Ryazanskiy NPZ" & $20-110$ & $0.1-0.4$ & 2.9 & 0.16 & 95.54 \\
\hline JSC "Novokuibyshevskiy NPZ" & $17-21$ & $0.3-1.0$ & $2.1-2.9$ & $0.07-0.12$ & 86.84 \\
\hline JSC "Slavneft-Yaroslavhefteorgsintez" & 42.8 & 0.1 & 2.8 & 0.1 & 93.46 \\
\hline
\end{tabular}




\begin{tabular}{|l|c|c|c|c|c|}
\hline \multicolumn{1}{|c|}{1} & 2 & 3 & 4 & 5 & 6 \\
\hline JSC "Moskovskiy NPZ" & 69 & 0.2 & 5.1 & 0.11 & 92.61 \\
\hline JSC "Norsi" & 76.4 & 0.3 & 2.7 & 0.2 & 96,47 \\
\hline JSC "Orskiy NPZ" & 54 & 0.2 & 6 & 0.2 & 88,89 \\
\hline JSC "Syzranskiy NPZ" & 78 & 0.2 & 2.1 & 0.1 & 97.31 \\
\hline Average for Russian Federation & 60.0 & 0.3 & $2-6$ & $0.03-0.2$ & 93,7 \\
\hline JSC "Kirishnefteorgsintez" [10] & 21.2 & 0.26 & 2.1 & 0.12 & 90.09 \\
\hline JSC "Ukrtatnafta" for 2003 year & 60.09 & 0.14 & $0.85-1.86$ & 0.11 & $96.9-98.6$ \\
\hline
\end{tabular}

\subsection{Neutralization of overheads of atmospheric columns}

The determination of neutralizing ability of nitrogenated agents used for the neutralization of overheads of atmospheric columns was carried out by potentiometric titration of product solutions with $1 \mathrm{~N}$ hydrochloric acid till $\mathrm{pH}$ value was in the range of 2-4. Neutralizing ability was calculated by formula (1).

Data of titration are represented in Fig. 3.

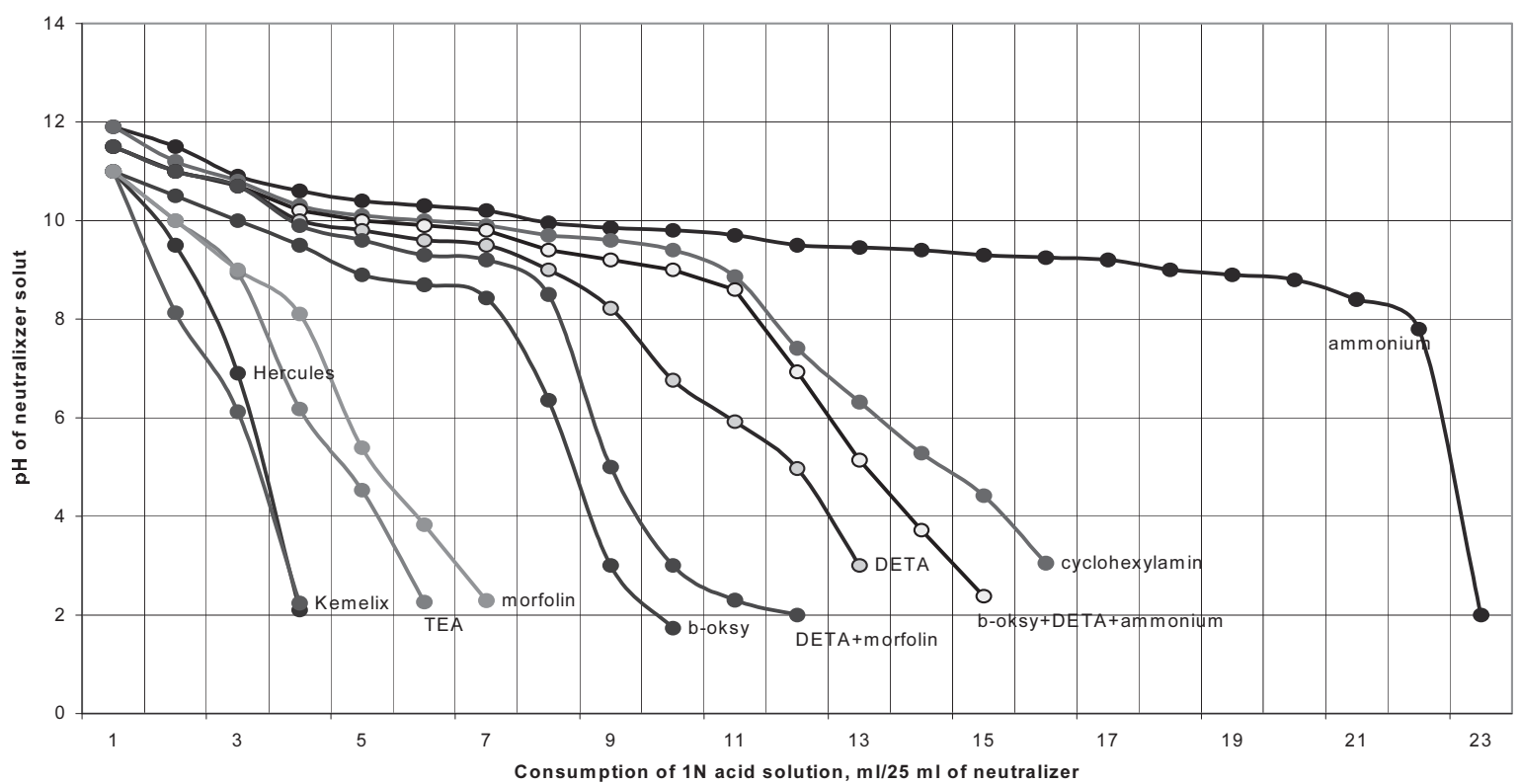

Fig. 3. Curves of potentiometric titration of organic neutralizers with hydrochloric acid

One can see from Fig. 3 that ammonia has the highest neutralizing ability. However it is very difficult to retain $\mathrm{pH}$ value in the range of $7-8$, since the least change of ammonia consumption causes sharp change of $\mathrm{pH}$. The other organic compounds are less effective, however titration curves of diethylenetriamine (DETA), betaoxyethylenediamine and cyclohexylamine are gentler in the problem interval of $\mathrm{pH}$. Therefore, above-mentioned samples were chosen for the following researches.

Commodity forms of neutralizers, as a rule, are 20-50\% solutions of active substances in water or hydrocarbon solvents. The concentration of active substance is determined by physical and chemical characteristics of products which in turn, determine the technological and operating characteristics of quality. Viscosity determines easy transportation and neutralizers batching; congelation temperature determines the lowest temperature at which neutralizer may be used.

On the basis of the fulfilled research the commodity form of DEOL-3241 neutralizer was developed. Cyclohexylamine was the active substratum of synthesized neutralizer. 


\subsection{Application of corrosion inhibitors}

Most of the described above corrosion inhibitors are widely used and continue to be used in oil industry of Ukraine. However, determination of efficiency of these inhibitors was carried out under different conditions (temperatures, inhibitors consumption, aggressiveness of media, etc.). So, we decided to compare efficiency of inhibitors used in Ukraine under identical conditions.
Efficiencies of Dodicor 3747, Kemelix 1123X, TAL-25-13-R, RENA-Naftokhim, OR-2K, AKS, DEOL4241 inhibitors were compared. Inhibitor consumption was in the range of 10-100 g/ton depending upon medium corrosiveness.

Experiments were carried out in monophase and diphasic media. The results of the research of inhibitor efficiency in a monophase medium are presented in Fig. 4.

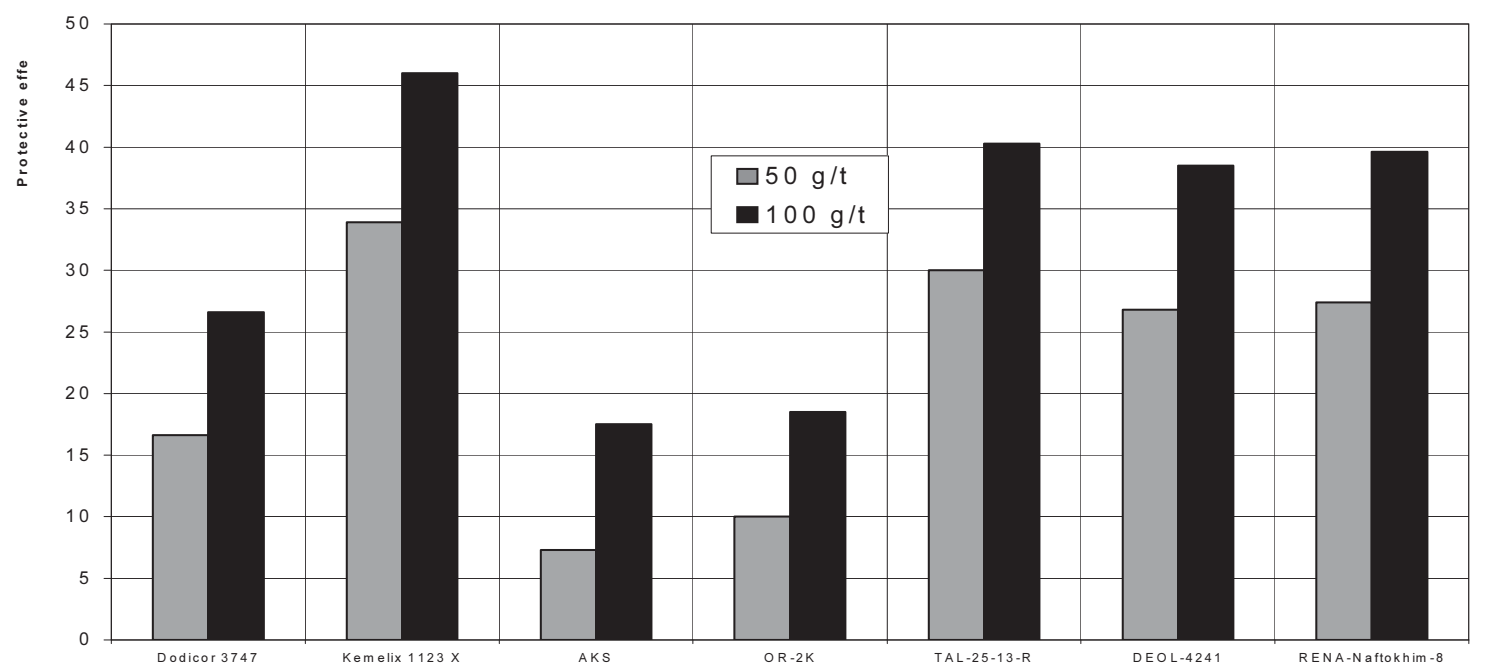

Fig. 4. Inhibitors protective effect in monophase medium

Inhibitor specific consumption was in the range of $50-100 \mathrm{~g} /$ ton. The low level of protective action of all inhibitors is explained by high corrosive activity of the medium. Under the desired conditions Kemelix 1123X, TAL-25-13-R, RENA-Naftokhim-8 and DEOL-4241 had the greatest efficiency. Other inhibitors showed less protective action in the investigated monophase medium. The results of the researches of inhibitor efficiency in diphasic medium are presented in Fig. 5.

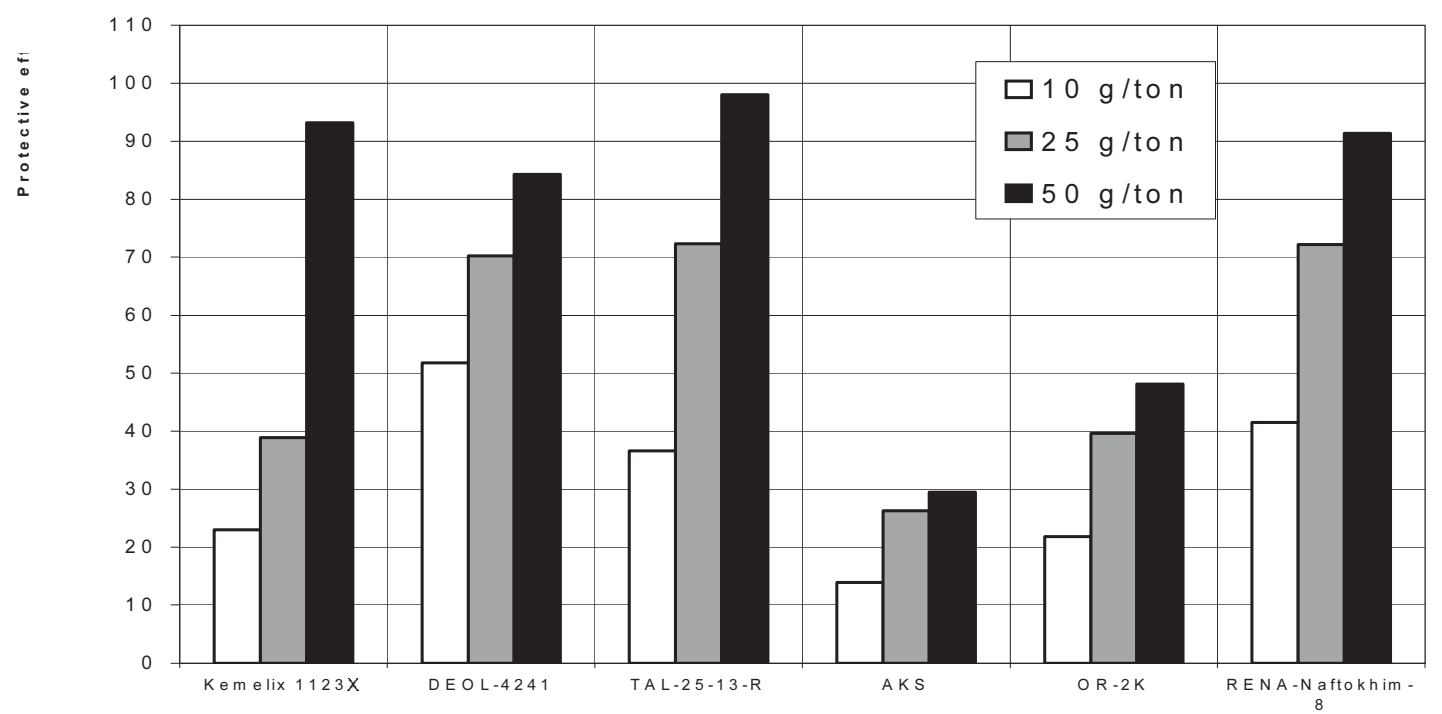

Fig. 5. Inhibitors protective effect in diphasic medium 
Similar to previous cases Kemelix 1123X, TAL-2513-R, RENA-Naftokhim-8 and DEOL-4241 had the greatest efficiency. DEOL-4241 was the most effective at consumption equal to $10 \mathrm{~g} / \mathrm{ton}$. At consumption of $25 \mathrm{~g} /$ ton its efficiency is commensurate with efficiencies of TAL-25-13-R and RENA-Naftokhim- 8 inhibitors. The increase of specific consumption of AKS and OR-2K inhibitors higher than $25 \mathrm{~g} /$ ton practically does not influence their efficiencies.
One can see that inhibitor efficiency depends on its concentration in an aggressive medium and on medium nature. Graphic comparison of inhibitor efficiency in different media at the specific consumption of $50 \mathrm{~g} /$ ton is represented in Fig. 6. Characters of inhibitors action are different. Some of them have low efficiency both in monophase and in diphasic media, e.g. OR-2K and AKS. Some of them have high efficiency in both media, e.g. DEOL-4241, TAL-2513-R, Kemelix 1123X, RENA-Naftokhim-8.

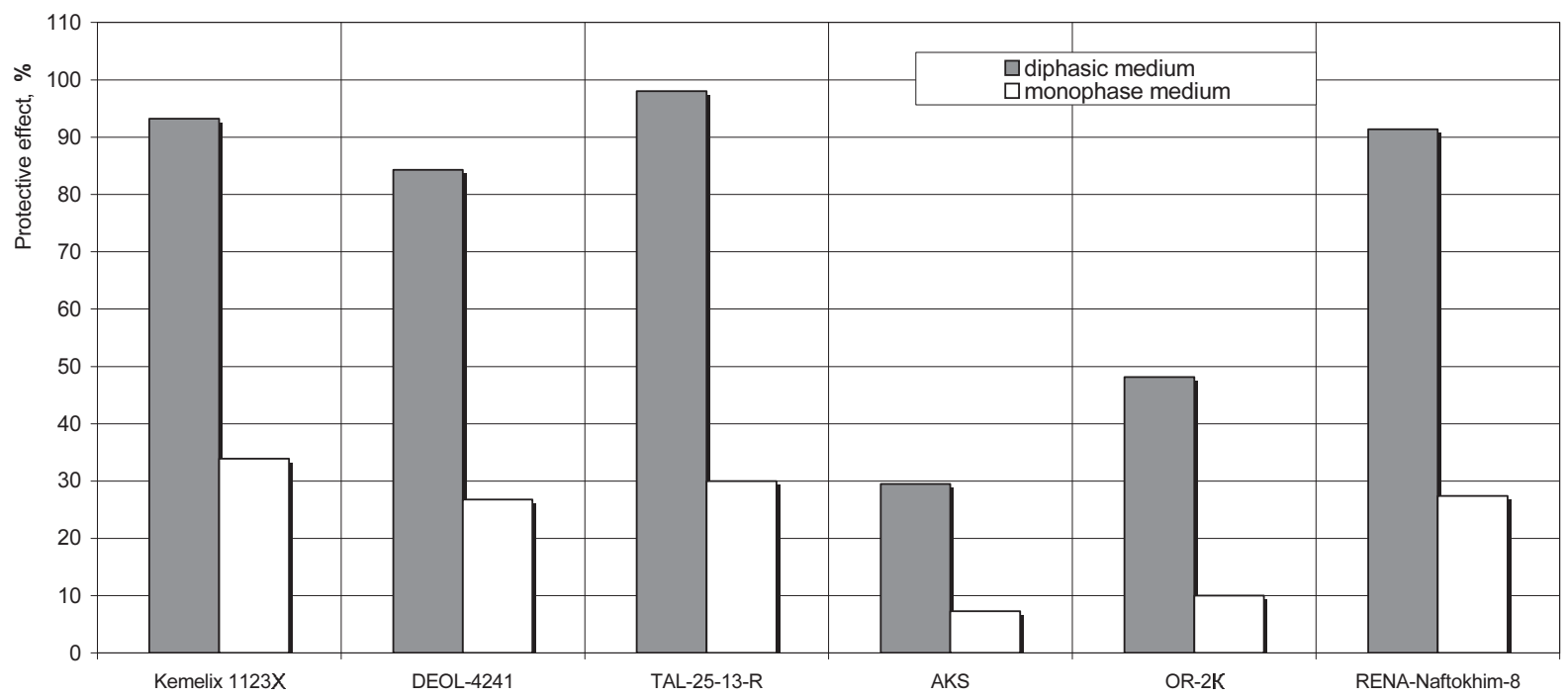

Fig. 6. Inhibitors protective effect in monophase and diphasic media at specific consumption of $50 \mathrm{~g} / \mathrm{ton}$

So, we can conclude that efficiencies of explored inhibitors depend on their specific consumption and medium nature.

Experimental results show that DEOL-4241, RENANaftokhim-8, TAL-25-13-R and Kemelix 1123X are most effective inhibitors. Efficiencies of these demulsifiers are commensurate. They have the same high efficiency both in monophase and diphasic media.

Expedience of the applicatoion of any corrosion inhibitor can be determined only after investigation and production tests and correlation of inhibitor consumption with its cost.

\section{Conclusions}

1. Non-ionogenic demulsifier based on ethylene and propylene was synthesized. The chemical structure of demulsifier was patented.

2. The dehydration and desalting of oil emulsions were investigated using synthesized demulsifier and other industrial demulsifiers.

3 . It was established that demulsifier consumption was in the range of 5-20 g/ton and depended upon emulsion characteristic.
4. Different types of neutralizers for acid components and corrosion inhibitors of refinery equipment were examined.

5. The optimal compositions of neutralizer based on cyclohexylamine and corrosion inhibitor based on amides of polyamine naphthenic acids were chosen.

\section{References}

[1] Topilnitskij P., Lepak V. and Litvyn B.: Materialy konferencii "Razrabotka, proizvodstvo i primenenie khimicheskih reagentov dlya neftyanoi i gazovoi promyshlennosti”, 2002, Moskwa.

[2] Faizullin Sh., Mashkov V., Semenov E., Koshchii V., Nesterenko S. and Bogatchuk Yu.: Neftepererabotka i neftekhimiya, 2003, 10, 50.

[3] Kostenko A. et al.: Neftepererabotka i neftekhimiya, 2004, 6,36.

[4] TU U 23.2-22340203-036:2006 Inhibitor corrosii "DEOL4241 ".

[5] Faizullin Sh., Mashkov V., Semenov E., Koshchii V., Nesterenko S. and Bogatchuk Yu.: Neftepererabotka i neftekhimiya, 2003, 10, 50.

[6] GOST 9.506-87 ES3KS. Inhibitory corozii metalov v vodnoneftyanyh sredah. 
[7] Leitar S., Savon'ko M., Topilnitskij P. and Maksymyk V.: Naftova I gazova promyslovist, 2004, 2, 50

[8] Trocenko V., Topilnitskij P. and Maksymyk V.: Naftova i gazova promyslovist, 2004, 3, 57.

[9] Hutoryanskiy F. et al.: Mir nefteproductov, 2002, 3, 17.

[10] Hutoryanskiy F. et al.: Mir nefteproductov, 2003, 3, 11.

\section{ЗАХИСТ ВІД КОРОЗЇ̈ НАФТОВИДОБУВНОГО ТА НАФТОЗАВОДСЬКОГО ОБЛАДНАННЯ}

Анотація. Представлено огляд методів захисту промислового обладнання від корозії. Вивчено застосування технологічних заходів з використанням хімічних реагентів та поверхнево-активних сполук, а саме зневоднення та знесолення вуглеводневої продукиії родовищ за допомогою поверхнево-активних речовин деемульгаторів, використання інгібіторів корозії та нейтралізуючих агентів для захисту конденсаційнохолодильного обладнання та верхніх погонів атмосферних колон. Встановлено витратні показники реагентів та умови проведення процесів.

Ключові слова: корозія, захист від корозії, нафтова емульсія, знесолення, зневоднення, поверхнево-активні речовини, деемульгатор, нейтралізатор, інгібітор корозії, захисний ефект. 